\title{
Effect of Electromagnetic Field and Allicin as Natural Extract on Hepatocellular Carcinoma (HepG2)
}

\author{
MAHA ANWER, Ph.D.*; ALY FAHMY MOHAMED, Ph.D.** and HALA ABD EL AZIZ, M.Sc.** \\ The Department of Biophysics, Faculty of Sciene, Cairo University* and The Holding Company for Production of Vaccines, \\ Sera and Drugs (VA CSERA)**
}

\begin{abstract}
Background: Cancer is one of the major public burdens worldwide. It is a multicellular disease that can arise from all cell type. In the recent decades, the number of cancer related showed a clear elevation, in turn creating huge health and economic problems. Non-ionizing Electromagnetic Fields (EMF), from extremely-low frequency to radiofrequency, have been shown to cause biological effects even at low intensity. Some of these effects may be applied for medical treatments. Exposure to PEMFs in the $0-300 \mathrm{~Hz}$ range is a thera-peutic tool extensively used for the treatment of several pathologies. Allicin is an organic sulfur compound from the bulbs of Allium sativum, which is also present in onions and other Allianceae plants. Allicin has strong antibacterial and anti-inflammatory effects, and may inhibit the growth of or kill various bacteria, fungi and viruses. A previous epidemiological study dem-onstrated the antitumor activity of allicin has been shown to directly kill tumor cells, inhibit tu-mor cell proliferation and induce apoptosis.
\end{abstract}

Aim of Study: This study investigates the anticancer activity of EMF, allicin and combination be-tween them in the treatment of Hepatocellular carcinoma (HepG2).

Material and Methods: Human Hepatocellular carcinoma (HepG2) ATCC®HB-8065 cell lines was supplied from Research and Development Sector, The Holding Company for production of Vac-cines, Sera and Drugs (VACSERA), Cairo, Egypt. Electromagnetic fields exposure, Allicin 95\% was kindly supplied from the national organization for drug control and research (NODCAR). Cytotoxicity, Flowcytometry and Quantitative Real Time RT PCR (q RT-PCR) anticancer activity of EMF, EMF-Allicin and Allicin compared to cisplatin was investi-gated through the expression of BAX, P53 and BCL2 genes using real time RT-PCR.

Results: Data revealed that cytotoxicity was concentration and cell type dependent, as lower concentration enhanced the higher viability profile, the concentration of allicin of $2 \mu \mathrm{g} / \mathrm{ml}$ cell viability reached $100 \%$ on both of vero cells and HepG2 cells. The inhibitory con-centration (IC50) for Vero cells, and HepG2 was $9.47 \mu \mathrm{g} / \mathrm{ml}$ and $69.4 \mu \mathrm{g} / \mathrm{m}$ respectively. The treatment with both EMF-Allicin is more efficient than treatment with EMF or Allicin separately. In the present study there was

Correspondence to: Dr. Maha Anwer, The Department of Biophysics, Faculty of Sciene, Cairo University a significant up regulation of both pro-apoptotic genes (BaxP53) accompanied by significant down regulation of antiapop-totic gene (BCL-2) relative to exposure to EMF + Allicin.

Conclusion: EMF can be used in therapy as its noninvasive technique used for the treatment of several pathologies and cancer.

Combination between EMF + Allicin can induce apoptosis and inhibition of proliferation in HepG2 cell line.

Key Words: Cancer - Electromagnetic field - Allicin - Hepatocellular carcinoma.

\section{Introduction}

CANCER is a group of more than two hundreds neoplastic diseases, all of which are caused by deregulation of multiple cell signaling pathways [1] characterized by uncon-trolled growth and spread of abnormal cells. If the spread of abnormal cells is not con-trolled, it can result in death [2] Cancer involves genetics and epigenetic changes asso-ciated with molecular alterations involving certain types of genes, such as proto-oncogenes and tumor suppressor genes, as a result of genetic predisposition [3]. Various therapies have been used for treating cancer such as surgery, radiotherapy, chemother-apy, and hormone therapy [4] Despite these therapeutic options, cancer remains asso-ciated with high mortality. Natural and some synthetic compounds can prevent, sup-press, or reverse the progression of cancer [5]. Electromagnetic fields contain both an electrical field and magnetic field. EM fields are classified in terms of their frequency of oscillation, ranging from DC through Extremely Low Frequency (ELF), low frequency, Radio Frequency (RF), microwave and infrared, visible light, ultra violet, $\mathrm{X}$-rays, and gamma rays [6]. The beginning of the 20 th century saw the first medical applications of Electromagnetic Fields (EMF), notably in the diagnosis and therapy of various diseases such as cancer. 
The assumption was that external application of electromagnetic energy could correct diseasecausing altered electromagnetic frequencies or energy fields within the body [7]. All medical devices aimed at treating cancer using low levels of electric and/or magnetic fields were considered quackery because of lack of scientific proof [8] The proposed action of pulsed EMF is through the induction of directed migration and dif-ferentiation of bone marrow-derived mesenchyme stem cells [9]. RF EMF is used as a therapeutic option in cases ranging from tibia stress fractures to spinal cord injury. Radiofrequency Ablation (RFA) is a therapeutic option commonly used to treat malignancies including breast cancer, colorectal cancer, and Hepatocellular Carcinoma (HCC), and especially surgically unrespectable metastases [10]. EMF range of the spectrum may have anti-tumor effects without causing hyperthermia in patients with breast cancer, HCC, ovarian cancer, thyroid cancer, or glioblastoma multiform [11]. Costa et al., [12] reported surprising clinical benefits from using the specific AM-EMF signals to treat ad-vanced hepatocellular carcinoma, stabilizing the disease and even producing partial responses up to 58 months in a subset of the patients. Zimmerman et al., [13] examined the growth rate of human tumor cell lines from liver and breast cancers along with normal cells from those tissues exposed to AMEMF. Reduced growth rate was observed for tumor cells exposed to tissue specific AM-EMF, but no change in growth rate in normal cells derived from the same tissue type. PEMF therapy does not only lead to the decrease of pain but it also decreases inflammation, increase cellular permeability, increase metabolism, increase cell energy storage and activity, flexibility and elasticity, and most of all it stimulates cellular and communication replication. In vitro and in vivo studies documented the anticancer effects of alternating electric fields [14] including low-intensity intermediate frequency $(100-300 \mathrm{KHz})$ alternating electric fields, as well as amplitude-modulated Electromagnetic Fields (EMF) of somewhat lower frequencies $(0.1 \mathrm{~Hz}$ to 114KHz) [15]. Zimmerman et al., [16] showed that anticancer effects were achieved at specific (for the cancer cell type) modulation frequencies and demonstrated proliferative inhibition and mitotic spindle disruption following exposure to alternating electric fields. Furthermore, bridging important aspects of apoptosis [17] with Extremely Low Frequency (ELF) pulsed-gradient magnetic fields. Harris et al., [18] showed that ELF might be capable of exacerbating an inherent or induced genetic instability by reducing or attenuating the stringency of the late-cycle (G2) checkpoint. Cameron et al.,
[19] found that mice received either gamma irradiation IR or EMF therapy had significantly fewer lung metastatic sites and slower tumor growth than did untreated mice. Also they did not find harmful side effects with EMF. Initial clinical results in various tumour entities/sites (recurrent glioblastoma multiforme, hepatocellular carcinomas, breast carcinomas) were encouraging [20]. PEMF exposure was cytotoxic to MCF7 cells, but not to normal breast epithelial cells (MCF10). Both MCF7 and MCF10 cells were exposed to PEMF therapy and the cytotoxic indices were measured in order to design PEMF paradigms that could reduce selectively neoplastic cell proliferation [21]. Several anticancer agents are naturally produced by a wide range of different organisms including microorganisms, plants, and animals. These natural products have an effect on cellular signaling and gene expression [22]. Natural products have proven to be the most reliable single source of new and effective anticancer agents [23]. There is increasing evidence that garlic and compounds isolated from garlic have significant antiproliferative effects on human cancer cells. Much of this work was reviewed by Pinto and Rivlin [24] and Knowles and Milner [25]. The effects were shown by garlic derivatives include induction of apoptosis, regulation of cell cycle progression and modification of pathways of signal transduction. Additionally, they reported that garlic derivatives appear to regulate nuclear factors associated with immune function and inflammation. In 1997, Zheng and co-workers [26] reported that the inhibitory effects of Allicin on proliferation of leukemia cells were associated with the cell cycle blockage at the S/G2M boundary phase and induction of apoptosis, this effect was exhibited on neoplastic (leukemia) cells, but not neoplastic cells. In the last few years, a number of reports have appeared concerning the ant proliferative effects of several compounds derived from garlic. Hong and co-workers studied the effects of DAS, DADS and garlic extract on p53-wild type H460 and p53-null type H1299 Non-Small Cell Lung Cancer (NSCLC) cells [27]. They reported that DAS or DADS treatment, but not garlic treatment, of both cell types resulted in the highest number of cells in an apoptotic state. DADS was found to be more effective in inducing apoptosis in NSCLC cells. In H460 cells, the level of p53 protein, which is involved in the activation of apoptosis by DNA damage, was increased following DADS treatment. DAS and garlic treatment of $\mathrm{H} 460$ cells induced a rise in the level of Bax (a cell death ag-onist) and a fall in the levels of Bcl2 (a cell death antagonist). It is well known that p53 activates the transcription of Bax and represses 
the expression of Bcl-2 [28]. Thus, this study demonstrated that DAS, DADS and garlic extract are effective in reduction of an antiproliferative gene in NSCLC and suggested that modulation of apoptosis-associated cellular proteins by DAS, DADS and garlic extract may be the mechanism for induction of apoptosis.

\section{Material and Methods}

Electromagnetic fields exposure:

TRENNSTELL TRAFO LTS602 230V 50/60Hz 2.0 A TTW GMBH 09380 Thalneim.

Allicin 95\% was kindly supplied from the $\mathrm{Na}-$ tional Organization for Drug Control and Research (NODCAR).

\section{Working:}

The research was conducted from 2017 to 2018, in the holding company for production of vaccines, sera and drugs (VACSERA).

\section{Cancer cell line:}

Human Hepatocellular carcinoma (HepG2) ATCC®HB-8065 cell lines was supplied from Research and Development Sector, The Holding Company for Production of Vaccines, Sera and Drugs (VACSERA), Cairo, Egypt.

Cells were grown in RPMI-1640 containing Lglutamine, non-essential amino acids. So-dium bicarbonate Sodium Pyruvate, 10\% Fetal Bovine Serum (FBS) and antibiotics $(100 \mathrm{U} / \mathrm{mL}$ penicillin and $100 \mathrm{mg} / \mathrm{mL}$ streptomycin) at $37^{\circ} \mathrm{C}$ in a humidified atmosphere of $5 \% \mathrm{CO} 2$

\section{Cytotoxicity:}

MTT assay is a sensitive, quantitative and reliable colorimetric method that measures viability of cells. The assay is based on the ability of mitochondrial lactate dehydro-genase enzyme (LDH) in living cells to convert the water soluble substrate 3-(4,5-dimethylthiazol-2-yl) 2,5 diphenyltetrazolium bromide (MTT) into a dark blue formazan which is water insoluble. Solubilization solution (dimethyl sulfoxide) was added to dissolve the insoluble purple formazan product into a colored solution. The absorbance of this colored solution can be quantified by measuring it using spectrophotometer at a wave length usually $570 \mathrm{~nm}$ [29] The cytotoxicity of Allicin was performed on HepG2, cell lines, and Vero cell as normal cell. The cell survival was evaluated according to [30] as the cell suspention $\left(2 \times 10^{5}\right.$ cells $\left./ \mathrm{ml}\right)$ was dispensed as $100 \propto 1$ in a 96-well plate and the plates were incubated for 24 hours at $37^{\circ} \mathrm{C}$ in humidified air atmosphere enriched with $5 \% \mathrm{Co}_{2}$. The growth medium was removed and $100 \propto 1$ of fresh media was added to each well of the plate except the first well of first six rows. $200 \propto 1$ of Allicin $(1000 \propto \mathrm{g} / \mathrm{ml})$ were added to first column. Test extract was twofold serially diluted. Negative cell control was considered. The plates were incubated at $37^{\circ} \mathrm{C}$ for 24-48 hours. The treatment me-dium was decanted and cells were washed three times using Phosphate Buffer Saline (PBS). MTT ( $5 \mathrm{mg} / \mathrm{mL}$ in PBS) solution was added to each well as $50 \propto 1 /$ well. The plates were incubated at $37^{\circ} \mathrm{C}$ in a humidified air atmosphere enriched with 5\% $\mathrm{Co}_{2}$ for 3-4 hours. The resulting MTT formazan complex was dissolved by addition of $50 \propto 1$ of DMSO. The "absorbance was measured at 570nm using ELISA plate reader (Biotek-Elx-800-USA). Cytotoxicity assay was performed in triplicate and the percentage of cell survival was calculated using following formula:

$$
\% \text { cell survival }=\frac{\text { Mean optical density of test }}{\text { Mean optical density }} \times 100
$$

The mean percentage cell survival was plotted against the corresponding concentration of Allicin or garlic and the IC 50 (50\% inhibitory concentration) value was determined using Masterplex-2010 reader program.

\section{Flowcytometry technique:}

For each group, flowcytometry was done using ANNEXIN V-FITC KIT supplied from Beckman Coulter, France. ANNEXIN V-FITC kit is an apoptosis detection kit based on the binding properties of Annexin V to Phosphatidylserine (PS) and on the DNA-intercalating capabilities of Propidium Iodide (PI). The samples were washed with PBS and centrifuged for 5 minutes at $500 \mathrm{x}$ at $4^{\circ} \mathrm{C}$. The supernatant was discarded and the cell pellet was suspended in binding buffer. $1 \propto 1$ of Annexin VFITC solution and $5 \propto 1$ of dissolved PI were added to the cell suspension and mixed gently. The tubes were kept on ice and stored in the dark for 15 minutes. $400 \propto 1$ of binging buffer was added and mixed gently. The cell preparation was analyzed using CyAn TM ADP Analyzer (Beckman Coulter).

\section{Quantitative Real Time RT PCR ( $q R T-P C R)$ :}

Anticancer activity of EMF, Allicin and EMF + Allicin compared to control and cisplatin was investigated through the expression of Bax, P53 and BCL2 genes using real time RT-PCR.

HepG2 cell lines exposed to EMF (one hour per day for three days), EMF + Allicin and Allicin. HepG2 cell lines treated with Cisplatin 
$(1 \mathrm{mg} / \mathrm{ml})$ as positive control was included and untreated flask was kept as negative control. Detached cells and residual adhered cells were collected and prepared for RT-PCR.

mRNA expression levels of cell apoptosis-related genes:

Total RNA was extracted from control and treated HepG-2 cancer cell lines using Gene RNA Purification kit (Fermantus-UK) according to the manufacturer's protocol.

The concentration and the integrity of RNA were assessed spectrophotometrically at 260/280 $\mathrm{nm}$. First-strand cDNA was synthesized with 1 of total RNA using a Quan-titect Reverse Transcription kit (Qiagen, Germany) in accordance with the manufac-turer's instructions.

These samples were subsequently frozen at a temperature of $-80^{\circ} \mathrm{C}$ until use for de-termination of the expression levels of P53, Bax and Bcl-2 genes using real-time PCR.

Quantitative real-time PCR was performed on a Rotor-Gene Q cycler (Qiagen, Ger-many) using QuantiTect SYBR Green PCR kits (Qiagen, Germany) and forward and re-verse primers for each gene. The nucleic acid sequences of the primers were as fol-lows: P53(F: 5'-TCA GAT CCT AGC GTC GAG CCC-3' \& R: 5'-GGG TGT GGA ATC AAC CCA CAG-3') \& Bax (F: 5'-ATG GAC GGG TCC GGG GAG CA-3' \& R: 5'-CCC AGT TGA AGT TGC CGT CA-3') as well as anti-apoptotic gene Bcl-2 (F: 5'-GTG AAC TGG GGG AGG ATT GT-3' \& R: 5'-GGA GAA ATC AAA CAG AGG CC-3') compared to $\beta$-actin as a housekeeping gene (F: 5'-CAA GGT CAT CCA TGA CAA CTT TG3' \& R: 5'-GTC CAC CAC CCT GTT GCT GTA G-3'). Real-time PCR mixture consisted of 12.5 2x SYBR Green PCR Master Mix, 1 lleach primer (10pmol/ L), CLAA, and 8.5 L Rasefree water in a total volume of 25 mplification conditions and cycle counts were at temperature of $95^{\circ} \mathrm{C}$ for $15 \mathrm{~min}$ for the initial activation, followed by 40 cycles of denaturation at $94^{\circ} \mathrm{C}$ for $15 \mathrm{~s}$, annealing at $60^{\circ} \mathrm{C}$ for $30 \mathrm{~s}$, and elongation at $72^{\circ} \mathrm{C}$ for 30s. Melting curves were per-formed after realtime PCR to demonstrate the specific amplification of single products of interest.

Relative fold changes in the expression of target genes (P53, Bax and Bcl-2) were ac-complished using the comparative $2^{-}{ }^{\Delta} \mathrm{Ct}$ method [31] with the $\beta$-actin gene as an internal control to normalize the level of target gene expression. $\Delta \Delta \mathrm{CT}$ is the difference between the mean $\Delta \mathrm{CT}$ (treatment group) and mean $\Delta \mathrm{CT}$ (control group), where $\Delta \mathrm{CT}$ is the difference between the mean CT gene of interest and the mean CT internal control gene in each sample. Logarithmic transformation was performed on fold change values before being statistically analyzed, using the fold change values of three replicates for each gene measured.

\section{Statistical analysis:}

All experiments were carried out in three independent tests. Data were expressed as the mean \pm Standard Deviation (SD) and analyzed using oneway analysis of variance (ANOVA). The results were considered statistically significant at probability $<0.05$.

\section{Results}

\section{1- Cytotoxicity:}

Allicin as a purified garlic derivative tested for their in Vitro cytotoxicity against hepatic cancer cell lines. Data revealed that cytotoxicity was concentration and cell type dependent, as lower concentration enhanced the higher viability profile, oppositely the higher doses significantly decreased viability Fig. (1).

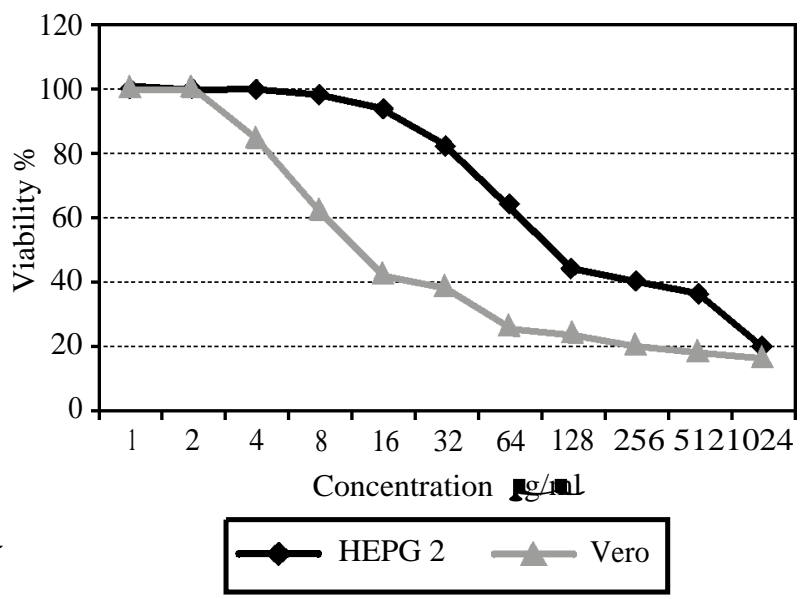

Fig. (1): Cytotoxicity of Allicin treated cells determined by MTT assay.

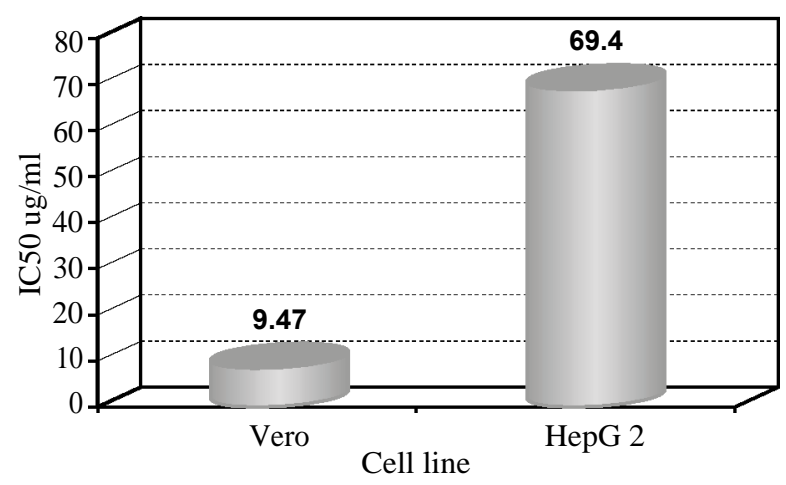

Fig. (2): ${ }_{\text {IC50 }}$ values of Allicin treated Vero, and HepG2 cells as determined by MTT as-say. 
The concentration of allicin of $2 \mu \mathrm{g} / \mathrm{ml}$ on vero cells, cell viability reached $100 \%(p<0.0007)$, and on HepG2 cells, cell viability reached $100 \%$ ( $p$ $<0.01)$ therefore, the non-cytotoxic concentration of allicin on the cells lines were $2 \mu \mathrm{g} / \mathrm{ml} \mathrm{Fig.} \mathrm{(1).}$
The inhibitory concentration (IC 50) for Vero cells, and HepG2 was $9.47 \mu \mathrm{g} / \mathrm{ml}$ and $69.4 \mu \mathrm{g} / \mathrm{m}$ respectively Fig. (2).

2- Evaluation of anticancer activity by Flowcytometry: Control (untreated) HepG2 cells line.

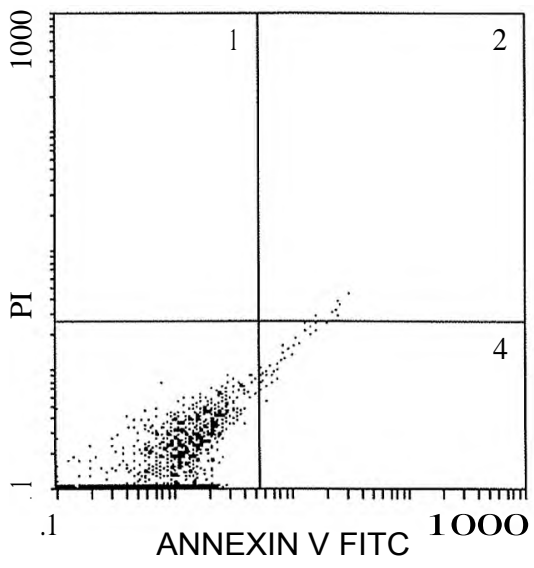

(A)

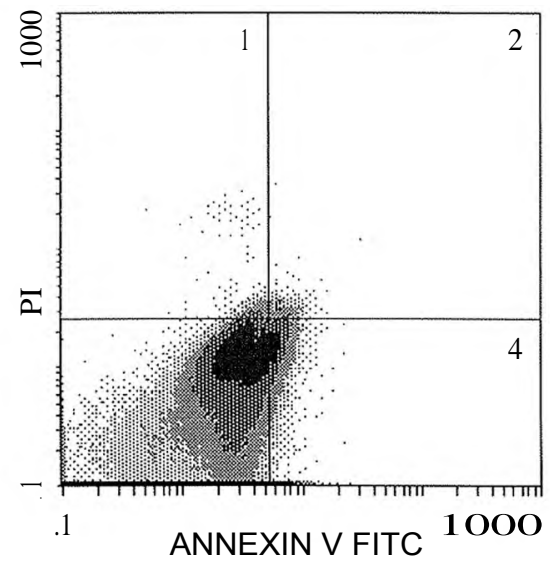

(B)

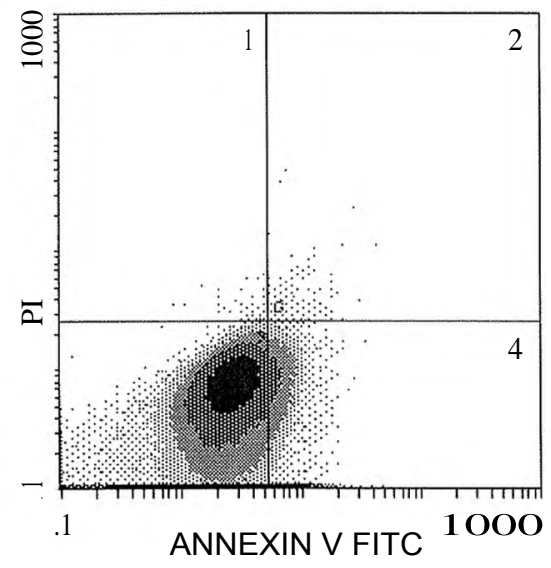

(C)

Fig. (3): (A-C) Histogram of HepG2 control 24hrs [A], 48hrs [B] and 72hrs [C] un-treated HepG2cell line presented via flow cytometric analysis using peopidium iodoide [P1] stain indicating the effect of exposure time on apoptotic profile 1: necrotic cells, 2: late apoptotic changes, 3 : viable cells and 4: early apoptotic changes.

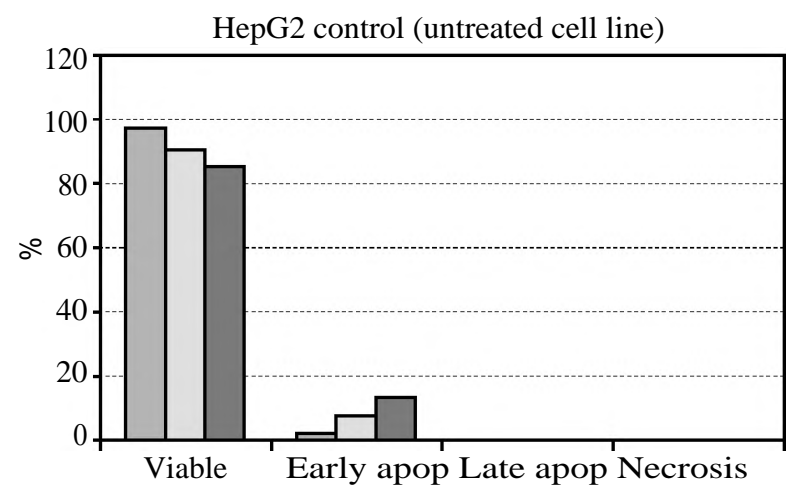
$24 \mathrm{hrs}$
$48 \mathrm{hrs}$
$72 \mathrm{hrs}$

Fig. (4): Chart showing percentage of apoptosis in control (untreated) HepG2 cells after $24 \mathrm{hrs}, 48 \mathrm{hrs}$ and $72 \mathrm{hrs}$.

HepG2 cell line exposed to $5 \mathrm{mT}$ :

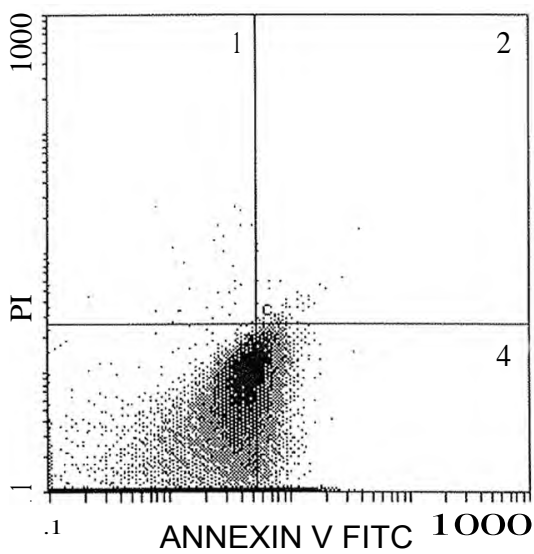

(A)

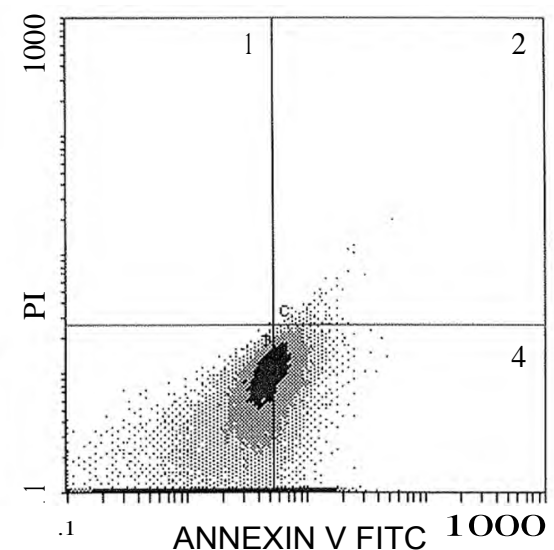

(B)

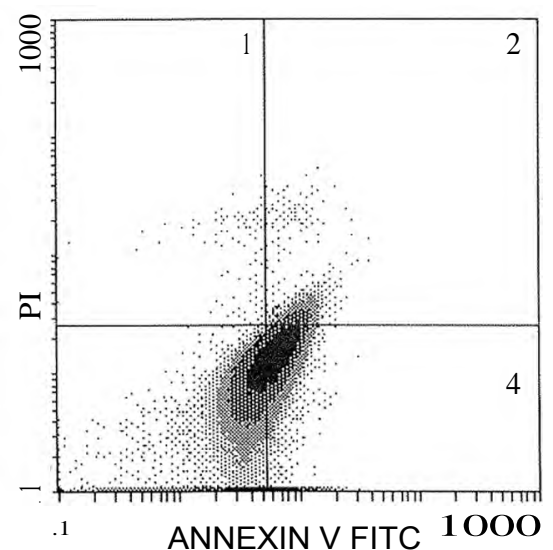

(C)

Fig. (5): (A-C) Histogram of HepG2 24hrs [A], 48hrs [B] and 72hrs [C] HepG2 cell line exposed to 5mT presented via flow cytometric analysis using peopidium io-doide [P1] stain indicating the effect of exposure time on apoptotic profile 1: necrotic cells, 2: late apoptotic changes, 3: viable cells and 4: early apoptotic changes. 
HepG2 cell line exposed to $5 m T$ and treated with Allicin:

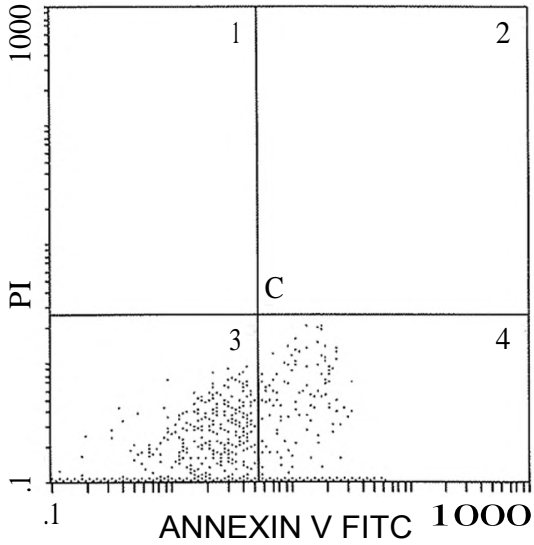

(A)

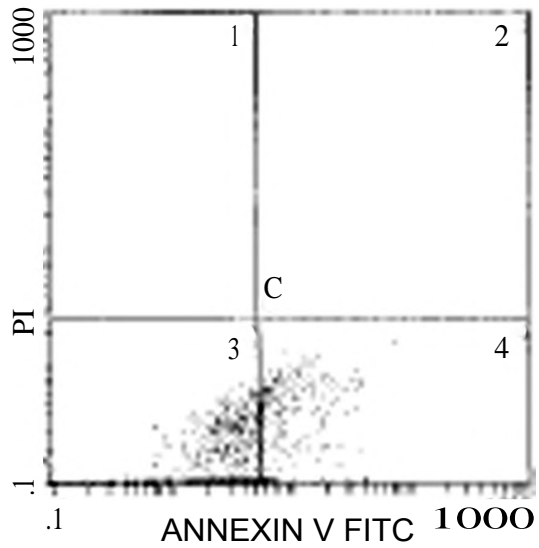

(B)

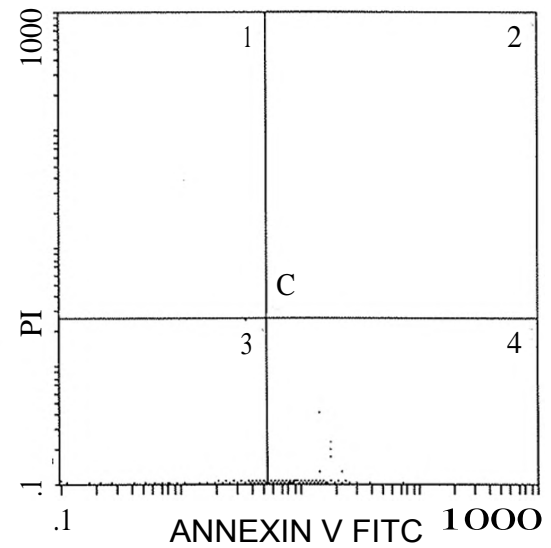

(C)

Fig. (6): (A-C) Histogram of HepG2 24h [A], 48h [B] and 72h [C] HepG2 exposed to 5mT and treated with Allicin presented via flow cytometric analysis using peopidium iodoide [P1] stain indicating the effect of exposure time on apop-totic profile 1: necrotic cells, 2: late apoptotic changes, 3: viable cells and 4: early apoptotic changes.

Data revealed that treatment with EMF-Allicin more efficient than EMF hence the percentage of viability was $29.80 \%$ and $41.80 \%$, early apop-

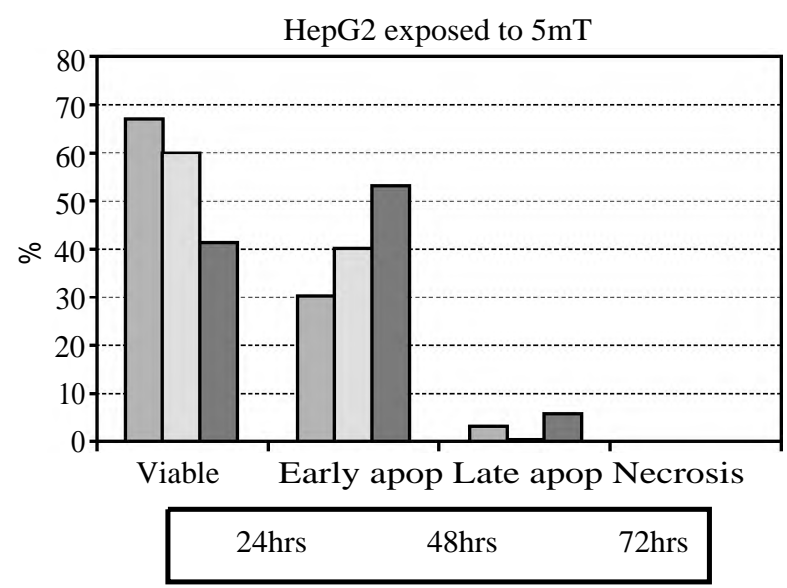

Fig. (7): Chart showing percentage of apoptosis in HepG2 cells exposed to $5 \mathrm{mT}$ after $24 \mathrm{hrs}, 48 \mathrm{hrs}$ and $72 \mathrm{hrs}$. tosis was $70.20 \%$ and $53.0 \%$ for EMF-Allicin and EMF treated HepG2 (after 72 hours at $5 \mathrm{mT}$ ) respectively.

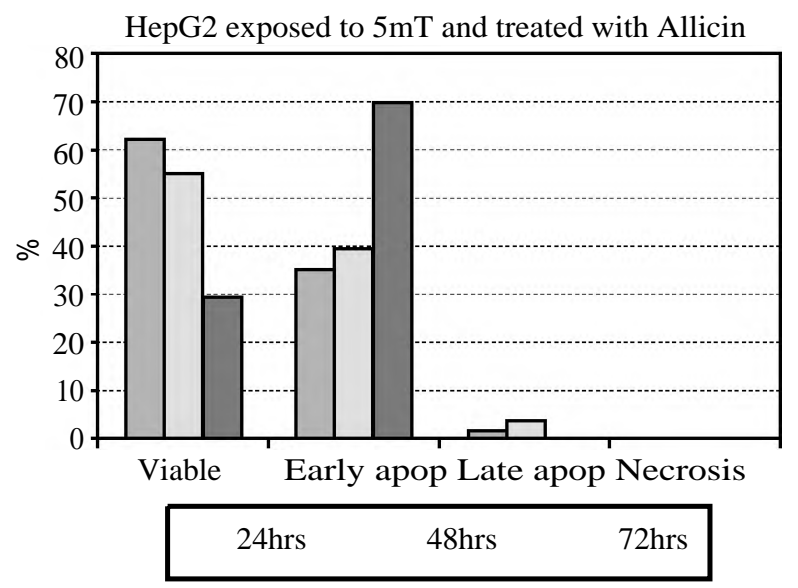

Fig. (8): Chart showing percentage of apoptosis in HepG2 cells exposed to $5 \mathrm{mT}+$ Allicin after $24 \mathrm{hrs}, 48 \mathrm{hrs}$ and $72 \mathrm{hrs}$.

\section{HepG2 treated with Allicin compared with Cisplatin:}

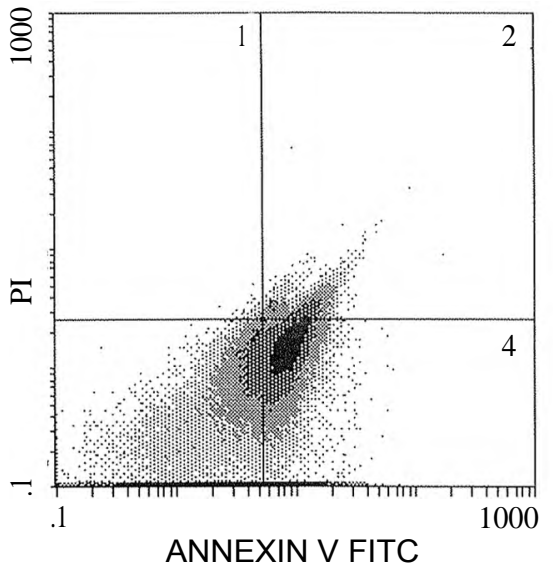

(A)

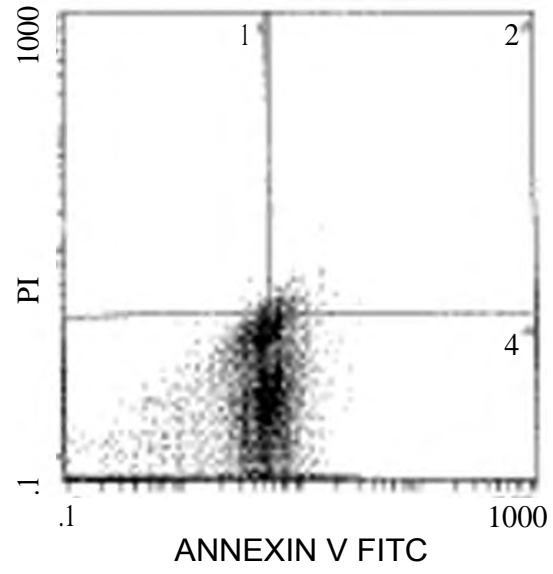

(B)
Fig. (9): Histogram of HepG2 treated with Allicin (A), treated with Cisplatin (B) presented via flow cytometric analysis using propidium iodoide [P1] stain indi-cating the effect of exposure time on apoptotic profile 1: necrotic cells, 2: late apoptotic changes, 3: viable cells and 4: early apoptotic changes. 


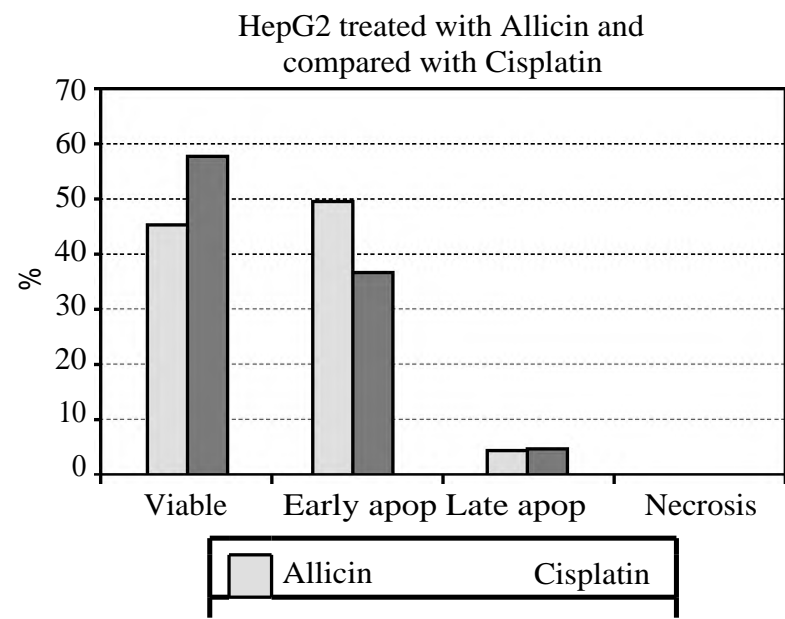

Fig. (10): Chart showing percentage of apoptosis in HepG2 cells treated with allicin and compared with Cisplatin.

mRNA expression levels of cell apoptosis-related genes:

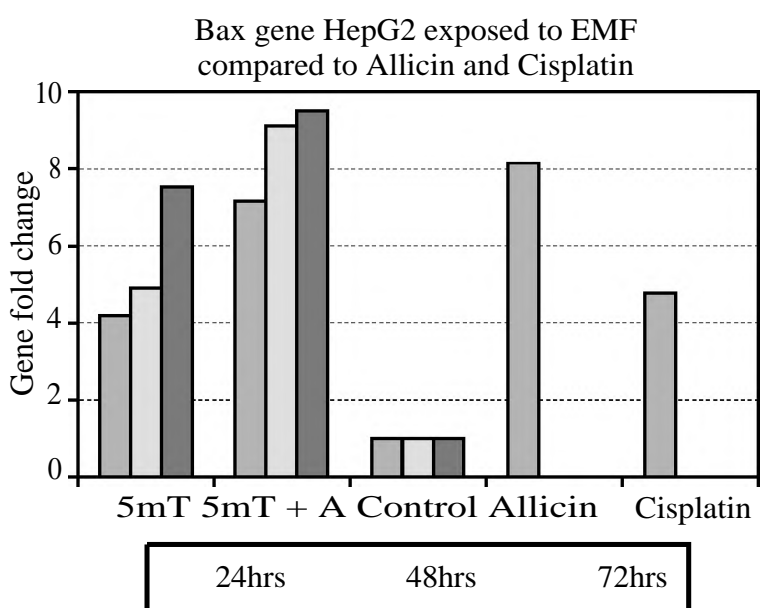

Fig. (11): Chart showing bax gene HepG2 cells exposed to $5 \mathrm{mT}$, exposed to $5 \mathrm{mT}+$ allicin, compared with allicin and Cisplatin.

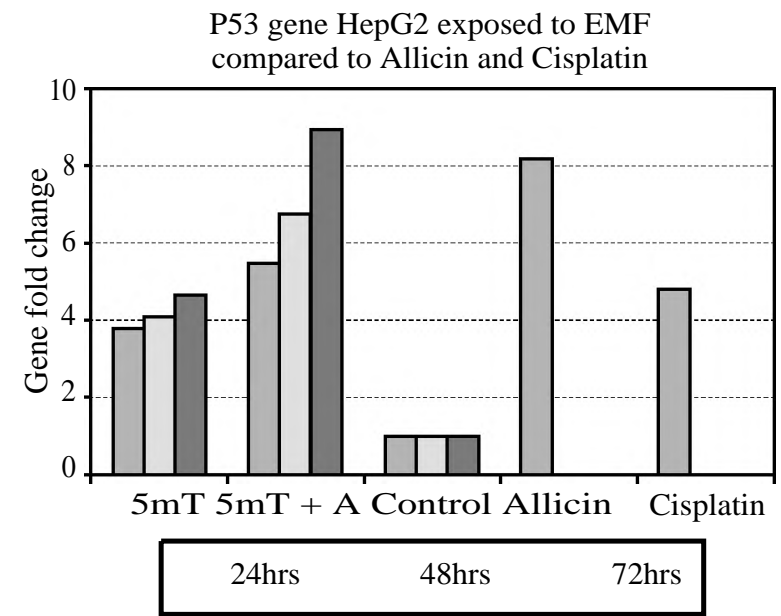

Fig. (12): Chart showing P53 gene HepG2 cells exposed to $5 \mathrm{mT}$, exposed to $5 \mathrm{mT}+$ al-licin, compared with allicin and Cisplatin.

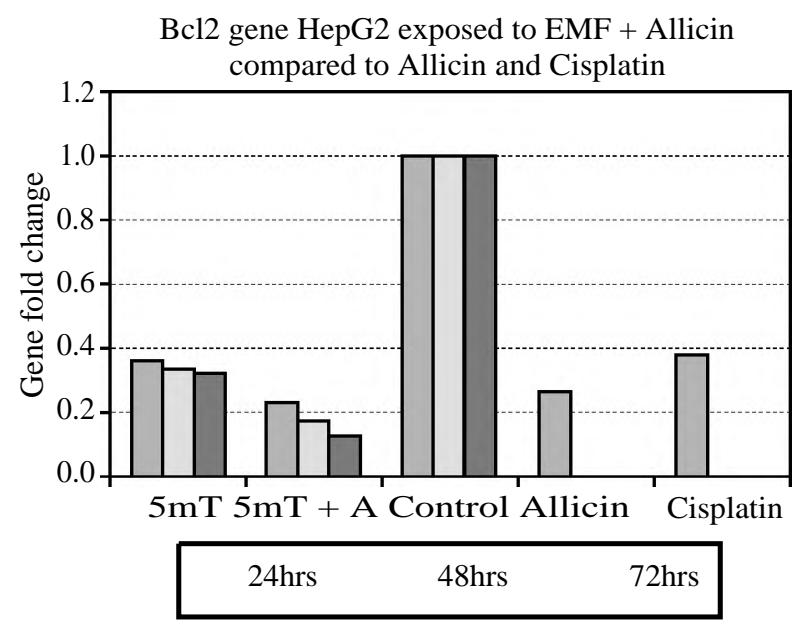

Fig. (13): Chart showing Bcl 2 gene HepG2 cells exposed to $5 \mathrm{mT}$, exposed to $5 \mathrm{mT}+{ }^{\circ} \mathrm{C}$ allicin, compared with allicin and Cisplatin.

\section{Discussion}

The MTT assay is based on the presumption that respiratory activity coincidences with cellviability. Allicin is able to inhibit many cysteinecontaining enzymes and if some mi-tochondrial reductases were targets of allicin, inhibition might lead to less MTT-reduction, although the cells are still viable. Alternative viability assays based on membrane-permeability (e.g., propidium-iodide) are also problematic since allicin is membrane active and forms transient pores in membranes [32]. This is in agreement with [33] who showed that allicin treatment decreases MTT reduction in other cells that allicin (conc.of $20 \mathrm{~g} / \mathrm{m} / \mathrm{L}, 60 \mathrm{~g} / \mathrm{m}$ and $100 \mathrm{~g} / \mathrm{n}-1)$ had a marked inhibitory effect on growth of HepG2 cells; moreover, HepG2 cell inhibition rate increased with increasing allicin concentration and treatment time. Annexin V-FITC one of the hallmarks of apoptosis is the externalization of phospholipid phosphatidylserine (PS) by translocation from the inner to outer layer of plasma membrane for recognition by phagocytes during early stage of apoptosis [34]. Hence, phosphatidylserine can serve as specific target for the detection of early apoptotic cells. This was accordance to [35] who stated that during the early phase of apoptosis, the integrity of the cell membrane is maintained but the cells lose the asymmetry of their membrane phospholipid. Stated that by using Annexin V-FITC as a probe provided direct evidence that PS exposure is a widespread event during apoptosis that occurs earlier than DNA associated changes and membrane leakage; Annexin $\mathrm{V}$ binding provides a useful general assay for detecting the onset of cell death. PEMFs can induce variable and species-specific alteration in the oxidative stress pathway such as $\mathrm{Ca}+{ }^{2}$-dependent oxidative 
stress which enhances free radical production, particulary via the fenton reaction leading to apoptotic cell death [36]. Allicin can induce apoptosis of cancer cells through activation of caspase 3 , caspase 8 and caspase 9 [37]. In the present study, RT-PCR was used to detect the expression of Bax, $\mathrm{P} 53$ and $\mathrm{Bcl} 2$ genes in HepG2 cells. In the present study showed that there was a significant up regulation of both pro-apoptotic genes (Bax-P53) accompanied with significant down regulation of anti-apoptotic gene (BCL-2) relative to exposure to $\mathrm{EMF}+$ Allicin $(p<0.05)$ compared with the control (untreated cells) and standard drug control; Cisplatin. All treatment showed positive apoptotic activity on both treated cancer cells compared to their expression level of control but with different potentials it was notice that the best effective treatment of liver cancer cell lines is the combination with EMF + Allicin at $5 \mathrm{mT}$ at 3 rd day of exposure (exposed 1 hour per day after 24, 48 and 72 hours) $p<0.05$. Several in vitro studies found that EMF effect on the membrane structure and permeability of small molecules, such as $\mathrm{Ca}+{ }^{2}$, and on cell proliferation [38], apoptosis [39], genotoxicity and cytoskeleton status, EMF at 50HZ, $2 \mathrm{mT}$ change in microtubule polymerization [40] EMF at $50 \mathrm{~Hz}, 2 \mathrm{mT}$ caused influence the transport of $\mathrm{Ca}^{+2}$ and hence, its homeostasis [41]. PEMF therapy exert proliferative inhibition and mitotic spindle disruption, block the development of neovascularization required for tumor supply [42] and exacerbate an inherent or induced genetic instability by reducing the stringency late-cycle $(\mathrm{G} 2)$ checkpoint [18]. While chemotherapy is not specific to cancer cells and targets all rapidly dividing cells [43], PEMF exert selective cytotoxic effect on neoplastic cells making this therapy a highly promising strategy. Garlic has been used worldwide as a spice, food, and folk medicine. It contains alliin [(1)-S-allyl-L-cysteine sulfoxide] as a major sulfurcontaining compound. When the raw garlic clove is damaged, alliin is hydrolyzed to sulfenate, pyruvate, and ammonia by alliinase. When garlic is crushed and chewed, alliinase convert alliin into allicin [44]. Antigenotoxic potential of purified garl ic compounds like Allicin, DAS, DADS, S-allyl cysteine (SAC) and allylmercaptan (AM) in human hepatoma cell line (HepG2) and found to protect human hepatic cells against the genotoxicity induced by indirect-and direct-acting genotoxic agents primarily by the inhibition of CYP enzymes and induction of phase II enzymes [45]. Allicin after only 24 hour of treatment, it prevented cells from entering the G2-M phase of the cell cycle, resulting in the accumulation of cells in the $S$ phase. The compounds such as ajoene and diallyl sulfide arrested the HL-60 human myeloid leukemia cells at the G2/M phase [46] while S-allylmercaptocysteine caused a G1 arrest in human umbilical vein endothelial cells. Allicin can induce the apoptosis of cancer cells through the activation of capase 3 , capase 8 and capase 9 [37]. [47] showed that Allicin stimulated p53-mediated autophagy and suppressed the proliferation of HepG2. In vitrocultured hepatoma cells treated with different doses of allicin found that intercellular junction reduced in majority of cells, cytoplasm shrank, marginrregular, intracellular granules increased, and typical apoptotic bodies appeared [42]. The combination of different ant tumor treatment strategies has greatly improved therapeutic efficacy in clinics. For example, combined chemotherapy can not only improved the therapeutic outcome by overcoming multidrug resistance and disrupting multiple cell survival pathways but also improve patient compliance due to reduced dosage of each agent [48] Untreated HepG2 cancer cell lines as a negative control groups were grown firmly a dherent, which were in irregular polygonal, fusiform or round shape. Cells were fully stretched, with intact membrane, uniform cytoplasmic distribution, cellular polymorphism (differentiation in cell size), hyperchromatism (dark nucleus) and karyomegaly (large nuclei took most part of cell). Adjacent cells were grown and fused into pieces. In comparison, EMF, Allicin, EMF-Allicin and Cisplatin treated HepG2 cellular polymorphism. Reduced intercellular junction and cell shrinkage were also observed. In addition, typical apoptotic characteristics were detected; such as apoptotic bodies and cell membrane blebbing. Antigenotoxic potential of purified garlic compounds like Allicin, DAS, DADS, Sallyl cysteine (SAC) and allylmercaptan (AM) in the human hepatoma cell line HepG2 and found to protect human hepatic cells against the genotoxicity induced by indirect-and direct-acting genotoxic agents primarily by the inhibition of CYP enzymes and induction of phase II enzymes [45] It has been reported that treatment of pancreatic cancer cells by $\mathrm{H} 2 \mathrm{~S}$ has been shown to induce apoptosis, resulting from the activation of caspase 3 , decreased protein level of Bcl-2 and activation of Bax expression [49]. As a conclusion, this study shows that EMF + Allicin induces inflammatory responses, inducing apoptosis in HEPG2 cancer cell lines through the up-regulation of pro-apoptotic gene, Bax and p53 all and down-regulation of antiapoptosis gene, $\mathrm{Bcl}-2$. As seen in the studies stated above, a large number of garlic components are believed to play a role in inhibiting cancer proliferation, of a number of cancer cell lines. Therefore, a better understanding of the pathways of the 
organosulfurs found as components of garlic is crucial in the advancement of garlic usage as drugs.

\section{References}

1- VOGELSTEIN B. and KINZLER K.W.: Cancer genes and the pathways they control. Nature Medicine, 10: 78999, 2004.

2- American Cancer Society: Cancer Facts and Figures. Atlanta, American Can-cer Society, 2014.

3- OMAR S., KHALED H., GAAFAR R., ZEKRY A.R., EISSA1 S. and EL-KHATIB O.: Breast-cancer in Egypt, a review of disease presentation and detection strategies, World Health Organization Regional Office for the References 122 Eastern Mediterranean, 9: 448-63, 2003.

4- World Health Organization: Cancer control: Knowledge into action: WHO guide for effective programmes, module 4. CH-1211 Geneva 27, Switzerland, 2008.

5- McCORMICK F.: Cancer gene therapy: Fringe or cutting edge. Nat. Rev., Cancer, 2: 130-41, 2001.

6- KITCHEN S. and S. BAZIN: Electrotherapy: EvidenceBased Practice. Churchill Livingstone, 2002.

7- Electromagnetic Therapy. American Cancer Society: Accessable at:http://www.cancer.org/treatment/ treatmentsand-sideeffects/complementaryandalternativemedicine/ manual-healingandphysicaltouch/electromagnetic-therapy, 2007.

8- Anonymous Questionable methods of cancer management: Electronic devices. CA Cancer J. Clin., 44: 115-27, 1994.

9- HRONIK-TUPAJ M., RICE W.L., CRONIN-GOLOMB M., et al.: Osteoblastic differentiation and stress response of human mesenchymal stem cells exposed to alternating current electric fields. Biomed Eng. Online, 10: 9, 2011.

10- RIPLEY R.T., GAJDOS C., REPPERT A.E., et al.: Sequential radiofrequency ablation and surgical debulking for unresectable colorectal carcinoma: Thermosurgical ablation. J. Surg. Oncol., 107: 144-7, 2013.

11- STUPP R., WONG E.T., KANNER A.A., et al.: Novottf100 a versus physician's choice chemo-therapy in recurrent glioblastoma: A randomised phase III trial of a novel treatment modality. Eur. J. Cancer, 48: 2192-202, 2012.

12- COSTA F.P., De OLIVEIRA A.C., MEIRELLES R., MACHADO M.C., ZANESCO T., SURJAN R., CHAMMAS M.C., De SOUZA ROCHA M., MORGAN D., CANTOR A., ZIMMERMAN J., BREZOVICH I., KUSTER N., BARBAULT A. and PASCHE B.: Treatment of advanced hepatocellular carcinoma with very low levels of amplitude-modulated electromagnetic fields. Br. J. Cancer, 105: 640-8, 2011.

13- ZIMMERMAN Z.W., PENNISON M.J., BREZOVICH I., NENGUN Y., YANG C.T., RAMAKER R., ABSHER D., MYERS R.M., KUSTER N., COSTA F.P., BARBAULT A. and PASCHE B.: Cancer cell proliferation is in-hibited by specific modulation frequencies. Br. J. Cancer, 106: 307-13, 2012.

14- VALONE T.: Bioelectromagnetic healing a rationale for its use (Integrity Re-search Institute, Washington, D.C.), 2007.
15- BARBAULT A., COSTA F.P., BOTTGER B., MUNDEN R.F., BOMHOLT F. and KUSTER N.: Amplitudemodulated electromagnetic fields for the treatment of cancer: Discovery of tumor-specific frequencies and assessment of a novel therapeutic approach. J. Exper. Clin. Cancer Res., 28: 51-10.1186/1756-9966-28-51, 2009.

16- ZIMMERMAN J.W., H. JIMENEZ, M.J. PENNISON, I. BREZOVICH, D. MORGAN, A. MUDRY, et al.: Targeted treatment of cancer with radiofrequency electromagnetic field amplitude-modulated at tumor-specific frequencies. Chin. J. Cancer, 32: 573-81, 2013.

17- FANG M., ZHANG H. and XUE S.: Role of calcium in apoptosis of HL-60 cells induced by harringtonine. Sci. China C Life Sci., 41: 600-7, 1998.

18- HARRIS P.A., LAMB J., HEATON B. and WHEATLEY D.N.: Possible attenuation of the G2 DNA damage cell cycle checkpoint in HeLa cells by extremely low frequency (ELF) elec-tromagnetic fields. Cancer Cell Int., 2: 310.1186/1475-2867-2-3, 2002.

19- CAMERON I.L., SUN L.Z., SHORT N., HARDMAN W.E. and WILLIAMS C.D.: Therapeutic Electromagnetic Field (TEMF) and gamma irradiation on human breast cancer xenograft growth, angiogenesis and metastasis. Cancer Cell Int., 5: 23-10.1186/1475-2867-5-23. doi: 10.1186/1475-2867-5-23, 2005.

20- COSTA F.P., De OLIVEIRA A.C., MEIRELLES R., MACHADO M.C., ZANESCO T., SURJAN R., CHAMMAS M.C., De SOUZA ROCHA M., MORGAN D., CANTOR A., ZIMMERMAN J., BREZOVICH I., KUSTER N., BARBAULT A. and PASCHE B.: Treatment of advanced hepatocellular carcinoma with very low levels of amplitude-modulated electromagnetic fields. Br. J. Cancer, 105: 640-8, 2011.

21- CROCETTI S., BEYER C., SCHADE G., EGLI M., FROHLICH J. and FRANCO-OBREGON A.: Low intensity and frequency pulsed electromagnetic fields selectively impair breast cancer cell viability. PLoS One, 8: e72944, 2013.

22- HARVEY A.: The role of natural products in drug discovery and development in the new millennium. I. Drugs, 13 (2): 70-2, 2010.

23- NEWMAN D. and CRAGG G.: Natural products as sources of new drugs bovver last 25 years. J. Nat. Prod., 70: 461-2, 2007.

24- PINTO J.T. and RIVLIN R.S.: Antiproliferative Effects of Allium Derivatives from Garlic. J. Nutr., 131: 1058S1060S, 2001.

25- KNOWLES L.M. and MILNER J.A.: Possible Mechanisms by which Allyl Sulfides Suppress Neoplastic Cell Proliferation. J. Nutr., 131: 1061S-1066S, 2001.

26- ZHENG S., YANG H., ZHANG S., WANG X., YU L., LU J. and LI J.: Initial Study on Naturally Occurring Products from Traditional Chinese Herbs and Vegetables for Chemoprevention. J. Cell. Biochem. Suppl., 27: 10612, 1997.

27- HONG Y.S., HAM Y.A, CHOI J.H. and KIM J.: Effects of Allyl Sulfur Compounds and Gar-lic Extract on the Expressions of Bcl-2, Bax, and p53 in Non Small CellLung Cancer Cell Lines. Exp. Molec. Med., 32: 127134, 2000. 
28- MIYASHITA T., KRAJEWSKI S., KRAJEWSKA M., WANG H.G., LIN H.K., LIEBERMANN D.A., HOFFMAN B. and REED J.C.: Tumor Suppressor p53 is a Regulator of bcl-2 and bax Gene Expression in vitro and in vivo. Oncogene, 9: 1799-805, 1994.

29- CORY A.H., OWEN T.C., BARLTROP J.A. and CORY J.G.: Use of an aqueous soluble tetrazolium/formazan assay for cell growth assays in culture. Cancer communication, 3 (7): 207-12, 1991.

30- MEHDI S.J., AHMAD A., IRSHAD M., MANZOOR N. and RIZVI M.M.A.: Cytotoxic effect of carvacrol on human cervical cancer cells. Bio Med., 3 (2): 307-12, 2011.

31- SCHMITTGEN T.D. and LIVAK K.J.: Analyzing realtime PCR data by the comparative CT method. N. Prot., 3 (6): 1101, 2008.

32- BERNAS T. and DOBRUCKI J.: Mitochondrial and nonmitochondrial reduction of MTT: Inter-action of MTT with TMRE, JC-1, and NAO mitochondrial fluorescent probes. Cytometry, 47: 236-42, 2002.

33- HAILIN YE, GUANXIONG YE, JINYAN JIANG, XIAOYA XU and CHENGJUN WU: Anti-proliferative effect of allicin on human hepatoma HepG2 cells. Biomedical Research, 27 (1): 195-8, 2016.

34- FADOK D.L. BRATTON S.C. FRASCH M.L. WARNER, and P.M. HENSON: "The role of phosphatidylserine in recognition of apoptotic cells by phagocytes," Cell Death \& Differentiation, Vol. 5, No. 7, pp. 551-62, 1998.

35- DIAZ C. and SCHORIT A.: Role of translocases in the generation of phosphatidylseriene asymmetry. J. Membrane Biol., 151: 1-9, 1996.

36- BARRERA-GARCIA A., T.O. HARA, F. GALVANMAGANA, L.C. MENDEZ-RODRIGUEZ, J.M. CASTELLINI and T. ZENTENO-SAVIN: Trace elements and oxidative stress indications in the liver and kidney on blue shark (prionace glauca). Comp. Biochem. Physiol. A mol. Integr. Physiol., 165: 483-90, 2013.

37- JAMEEL N.M., THIRUNAVUKKARASU C., WU T., WATKINS S.C., FRIEDMAN S.L. and GANDHI C.R. p38-MAPK-and caspase-3-mediated superoxide-induced apoptosis of rat he patic stel-late cells: Reversal by retinoic acid. J. Cell Physiol., 218: 157-66, 2009.

38- ZIMMERMAN J.W., PENNISON M.J., BREZOVICH I., YI N., YANG C.T., RAMAKER R., et al.: Cancer cell proliferation is inhibited by specific modulation frequencies. Br. J. Cancer.1, 106: 307-13. https://doi.org/10.1038/ bjc.2011.523PMID:22134506, 2012.
39- TOFANI S., D. BARONE M. CINTORINO M.M. De SANTI, A. FERRARA, R. ORLASSINO, et al.: Static and ELF magnetic fields induce tumor growth inhibition and apoptosis. Bioelectromagnetics, 22: 419-28, 2001.

40- KIRSON E.D., Z. GURVICH, R. SCHNEIDERMAN, E. DEKEL, A. ITZHAKI, Y. WASSERMAN, et al.: Disruption of cancer cell replication by alternating electric fields. Cancer Res., 64: 3288-95, 2004.

41- MANIKONDA P.K., P. RAJENDRA, D. DEVENDRANATH, B. GUNASEKARAN, B. CHANNAKESHAVA, R.S. ARADHYA, et al.: Influence of extremely low frequency magnetic field on $\mathrm{Ca}^{+2}$ signaling and NMDA receptor functions in rat hippocampus. Neurosci. Lett., 413: 145-9, 2007.

42- ZHANG X., ZHANG H., ZHENG C., LI C., ZHANG X. and XIONG W.: Extremely Low Frequency (ELF) pulsedgradient magnetic fields inhibit malignant tumour growth at different biological levels. Cell Biol. Int., 26: 599-603. 10.1006/cbir.2002.0883, 2002.

43- DeHAVEN C.: Chemotherapy and radiotherapy effects on the skin. Plast. Surg. Nurs., 34: 192-5, 2014.

44- YUN H.M., BAN J.O., PARK K.R., LEE C.K., JEONG H.S., HAN S.B. and HONG J.T.: Potentiai therapeutic effects of functionally active compounds isolated from garlic. Pharmacology \& Therapeutics, 142: 183-95, 2014.

45- BELLOIR C., SINGH V., DAURAT C., SIESS M.H. and Le BON A.M.: Protective effects of garlic sulfur compounds against DNA damage induced by direct-and indirect-acting genotoxic agents in HepG2 cells. Food and Chemical Toxicology, 44: 827-34, 2006.

46- DIRSCH V.M., GERBES A.L. and VOLLMAR A.M. Ajoene, a compound of garlic, induces apoptosis in human promyeloleukemic cells, accompanied by generation of reactive oxygen species and activation of nuclear factor kappaB. Mol. Pharmacol., 53: 402, 1998.

47- ZHANG W., HA M., GONG Y., XU Y., DONG N. and YUAN Y.: Allicin induces apoptosis in gastric cancer cells through activation of both extrinsic and intrinsic pathways. Oncology Reports, 24: 1585-92, 2010.

48- KANG L., GAO Z., HUANG W., JIN M. and WANG Q. Nanocarrier-mediated co-delivery of chemotherapeutic drugs and gene agents for cancer treatment. Acta Pham. Sin. B., 5: 169-75, 2015.

49- ADHIKARI S. and BHATIA M.: H2S-induced pancreatic acinar cell apoptosis is mediated via JNK and p38 MAP kinase. J. Cell Mol. Med., 12 (4): 1374-83, 2008. 


\section{تآثير المجال المغناطيسى ومادة الآليسن كمستخلص الصني طبيعى على خلايا الكبد السرطادة الإنية}

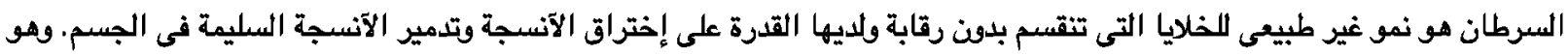

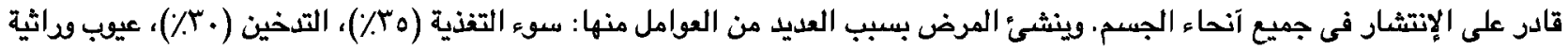

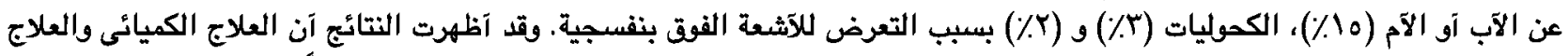

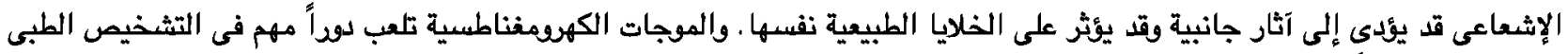

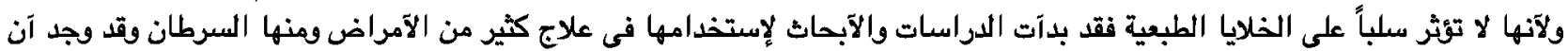

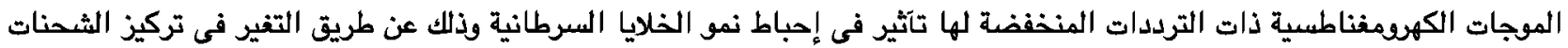

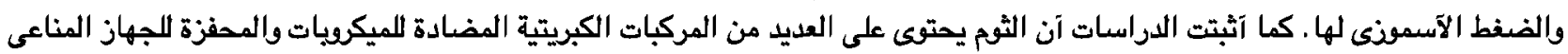
كما آنها تمنع تنشيط المواد المسرطنة وتعمل كذلك على تسريع التخلص منها إلى جانب قدرتها على خفض معدلات إنتشار الآحدام.

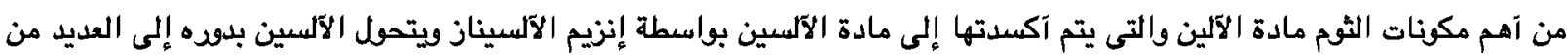

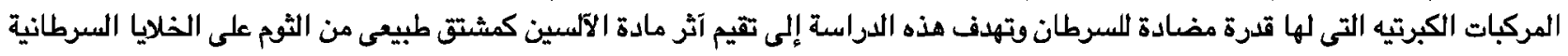

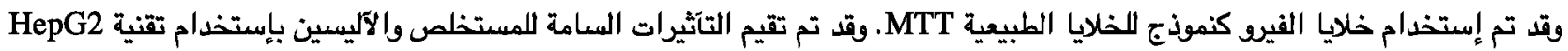

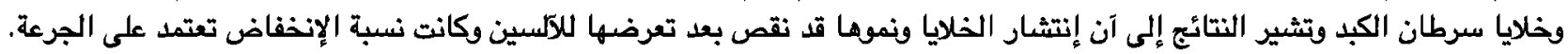

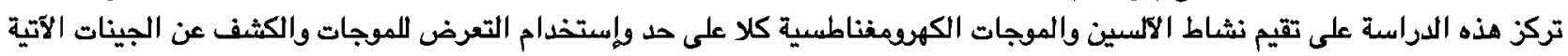

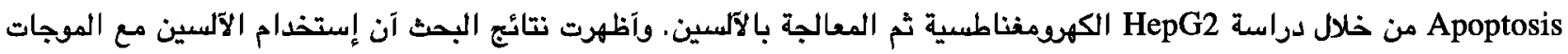
(2BCL, 53P, BAx)

نشاط gene Bax \& P53 ونقص نشاط ال BCL2 gene. 